\title{
Budget and distribution of organic carbon in Taxus cuspidata forest in subalpine zone of Mt. Halla
}

\author{
Rae-Ha Jang ${ }^{1}$, Heon-Mo Jeong ${ }^{2}$, Eung-Pill Lee ${ }^{1,3}$, Kyu-Tae Cho $^{1}$ and Young-Han You ${ }^{1 *}$
}

\begin{abstract}
Background: In order to investigate organic carbon distribution, carbon budget, and cycling of the subalpine forest, we studied biomass, organic carbon distribution, litter production, forest floor litter, accumulated soil organic carbon, and soil respiration in Taxus cuspidata forest in Halla National Park from February 2012 to November 2013. Biomass was calculated by using allometric equation and the value was converted to $\mathrm{CO}_{2}$ stocks.

Results: The amount of plant organic carbon was 13.60 ton C ha $^{-1}$ year $^{-1}$ in 2012 and 14.29 ton C ha ${ }^{-1}$ year $^{-1}$ in 2013. And average organic carbon introduced to forest floor through litter production was 0.71 ton $C$ ha $^{-1} \mathrm{year}^{-1}$. Organic

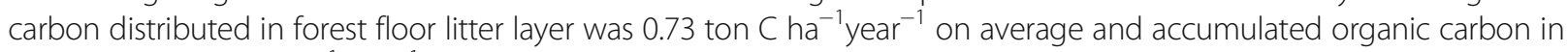
soil was 51.13 ton $\mathrm{C} \mathrm{ha}^{-1}$ year $^{-1}$ on average. In 2012, Amount of released $\mathrm{CO}_{2}$ from soil to atmosphere was 10.93 ton $\mathrm{CO}_{2}$ ha $^{-1}$ year $^{-1}$.
\end{abstract}

Conclusions: The net ecosystem production based on the difference between net primary production of organic carbon and soil respiration was -1.74 ton $\mathrm{C} \mathrm{ha}^{-1} \mathrm{yr}^{-1}$ releasing more carbon than it absorbed.

Keywords: Allometric, Carbon budget, Subalpine forest, Taxus cuspidate, Mt. Halla

\section{Background}

The main cause of global warming is $\mathrm{CO}_{2}$, a greenhouse gas, released into the atmosphere through both natural and human activities. The increase in the $\mathrm{CO}_{2}$ concentration greatly affects the lives of people and ecosystem (Jang et al. 1998). Recently, annual $\mathrm{CO}_{2}$ emission increased approximately by $80 \%$ from 1970 to 2004 due to high usage of fossil fuels and felling (IPCC 2007). Moreover, $\mathrm{CO}_{2}$ level increased by about $40 \%$ to $391 \mathrm{ppm}$ in 2011 compared to pre-industrial era (IPCC 2013). In Korea, atmospheric $\mathrm{CO}_{2}$ concentration $(405 \mathrm{ppm})$ was higher than the global average (400 ppm) in 2015 (Korea Meteorological Administration 2016; WMO 2016). According to the observational data from six observation stations (in Seoul, Incheon, Gangneung, Daegu, Mokpo, and Busan) between 1912 and 2009, the annual mean temperature

\footnotetext{
* Correspondence: youeco21@kongju.ac.kr

${ }^{1}$ Department of Biology, Kongju National University, Gongju, South Korea

Full list of author information is available at the end of the article
}

has risen by $1.7^{\circ} \mathrm{C}$ in that time. This figure was more than double the increase in global average temperature which was $0.74{ }^{\circ} \mathrm{C}$ (Korea Meteorological Administration 2009; IPCC 2007).

Therefore, various methods, such as United Nations Framework Convention on Climate Change (UNFCCC), are being discussed by the authorities in order to reduce greenhouse gases worldwide with focus on high level of $\mathrm{CO}_{2}$ concentration in the atmosphere. In 2012, Kyoto Protocol was revised by UNFCCC to commit state parties (developed countries) to significantly reduce greenhouse gas emissions from 2013 to 2020. In Paris Agreement announced by United Nations Climate Change Conference in 2015, not only advanced countries approve reduction of $\mathrm{CO}_{2}$ emission but also developing countries do. Korea also set a goal that amount of $\mathrm{CO}_{2}$ emission reduces up to $37 \%$ contrasted in Business As Usual. 
Atmospheric $\mathrm{CO}_{2}$ concentration is absorbed by marine and terrestrial ecosystem. Especially, more carbon is absorbed by terrestrial ecosystem than marine ecosystem (Ito and Oikawa 2004). There are about 160GtC from human sources that are accumulated in terrestrial ecosystem (IPCC 2013).

The greatest terrestrial carbon sinks occur in forest ecosystem through interaction of vegetation (Park et al. 2005).

It is stored in form of aboveground biomass, belowground biomass, dead trees, forest floor litter, and organic matters in soil but litter accounts for large portion of organic matter accumulated on the forest floor of the forest ecosystem (Ovington and Heitkamp 1960; Dixon et al. 1994; Hu and Wang 2008). Thus, forest ecosystem is getting the attention as the main carbon storeroom that can reduce $\mathrm{CO}_{2}$ level and many researches are under progress to analyze and enhance the carbon storage capability of forest ecosystem to prevent global warming (Law et al. 2001; Sohngen and Mendelsohn 2003; Richards and Stokers 2004; McKenny 2004).

Soil respiration is the second biggest flux in the global carbon cycle and soil respiration of the forest is an index that represents edaphon and root activities. Furthermore, an analysis of soil respiration is essential in order to calculate net primary production (NEP) and many studies have been carried out abroad already in order to accurately analyze the carbon cycle of forest ecosystem by quantifying $\mathrm{CO}_{2}$ released from the soil (Raich and potter 1995). The ability of forest ecosystem to reduce $\mathrm{CO}_{2}$ and store carbon is very important but most of the domestic studies on $\mathrm{CO}_{2}$ put their focus of emission of $\mathrm{CO}_{2}$. As result, there are not many studies on carbon budget of forests (Lee et al. 2013; Lee 2014).

Range of the subalpine zone boundaries is from timber line where commercial timber production is possible, to tree line that does not show tree upper 4-5 m height (Kim 1976; Kong 2002). And subalpine zone appears in the region with below 45 of warmth index (Yim 1977; Lee KS et al. 2013). These subalpine zones were more influenced by the increase in $\mathrm{CO}_{2}$ concentration than any other ecosystems (LaMarche et al. 1984). Therefore, the purpose of this study was to comprehend the social costs of natural resources that will be caused by climate change by quantitatively analyzing the carbon budget and distribution of T. cuspidata forest in subalpine zone of Mt. Halla.

\section{Methods}

\section{Study site}

Taxus cuspidata forest in the study site is located $1648 \mathrm{~m}$ above sea level by Yeongsiloreum in Mt. Halla with tree density of $3700 \mathrm{No} \mathrm{ha}^{-1}$ (Fig. 1). Mt. Halla
$(1950 \mathrm{~m})$ is the highest mountain in South Korea and it is a typical volcanic island. The annual average rainfall in the site is $1975 \mathrm{~mm}$ making it the area with highest rainfall in South Korea. Temperate zone can be observed from $600 \mathrm{~m}$ above sea level and subalpine zone can be observed from $1100 \mathrm{~m}$ where various vegetation are found according to vertical distribution. The temperature of Yeongsil region was the highest in August reaching approximately $16.7^{\circ} \mathrm{C}$ and lowest in December going down to $-2.5^{\circ} \mathrm{C}$. Relative humidity was the highest in August which was $89.5 \%$ and lowest in March and April which was $0.5 \%$ (Song 2011). There are plants of small height in subalpine zone of Mt. Halla compared with temperate forests (Fig. 2). In the tree layer of T. cuspidata community, there are T. cuspidata (dominant species), Rhododendron schlippenbachii and Berberis amurensis var. quelpaertensis. In the herb layer of T. cuspidata community, there are T. cuspidata, Lycopodium chinense, Sasa quelpaertensis, Primula modesta var. fauriae, Galium pusilum, Prunella vulgaris var. lilacina, Geranium thunbergii etc.

\section{Study period and plot}

In temperature forest, the shrubland and the tree layer forest were used with a quadrate of 9-25 $\mathrm{m}^{2}, 100-$ $200 \mathrm{~m}^{2}$ size, respectively (Yeocheon Ecological Research Society 2005; You et al. 2015; Barbour et al. 1999). Because of $T$. cuspidate community height in subalpine zone of Mt. Halla is $3 \mathrm{~m}$, we used quadrate of $10 \times 10 \mathrm{~m}$ size which was used for community studies (Jeong 2015; Lee and Mun 2001).

Quadrate was installed in February 2012 and study was conducted until November 2013 according to seasons. The study was conducted in spring (May), summer (August), and fall (November) each year because snowfall reaches over $1 \mathrm{~m}$ during winter.

\section{Biomass}

Summation method is probably the best method to measure the biomass, but it is difficult to measure the biomass by felling in Mt. Halla National Park. Therefore, summation method was used for herb layer.

The estimation made using diameter at breast height $(\mathrm{DBH})$ and allometric equation between each organ. The biomass of leaves and reproductive organ were measured from the litter collected in the litter trap each year. DBH was measured in April each year using measuring tape. The belowground biomass was calculated by applying $25 \%$ to the aboveground biomass (Johnson and Risser 1974). Allometric equation (Yasuhiro 2006; Kwak et al. 2004; Lee et al. 2004) used to estimate biomass of tree layer in this study is as follows Table 1. 


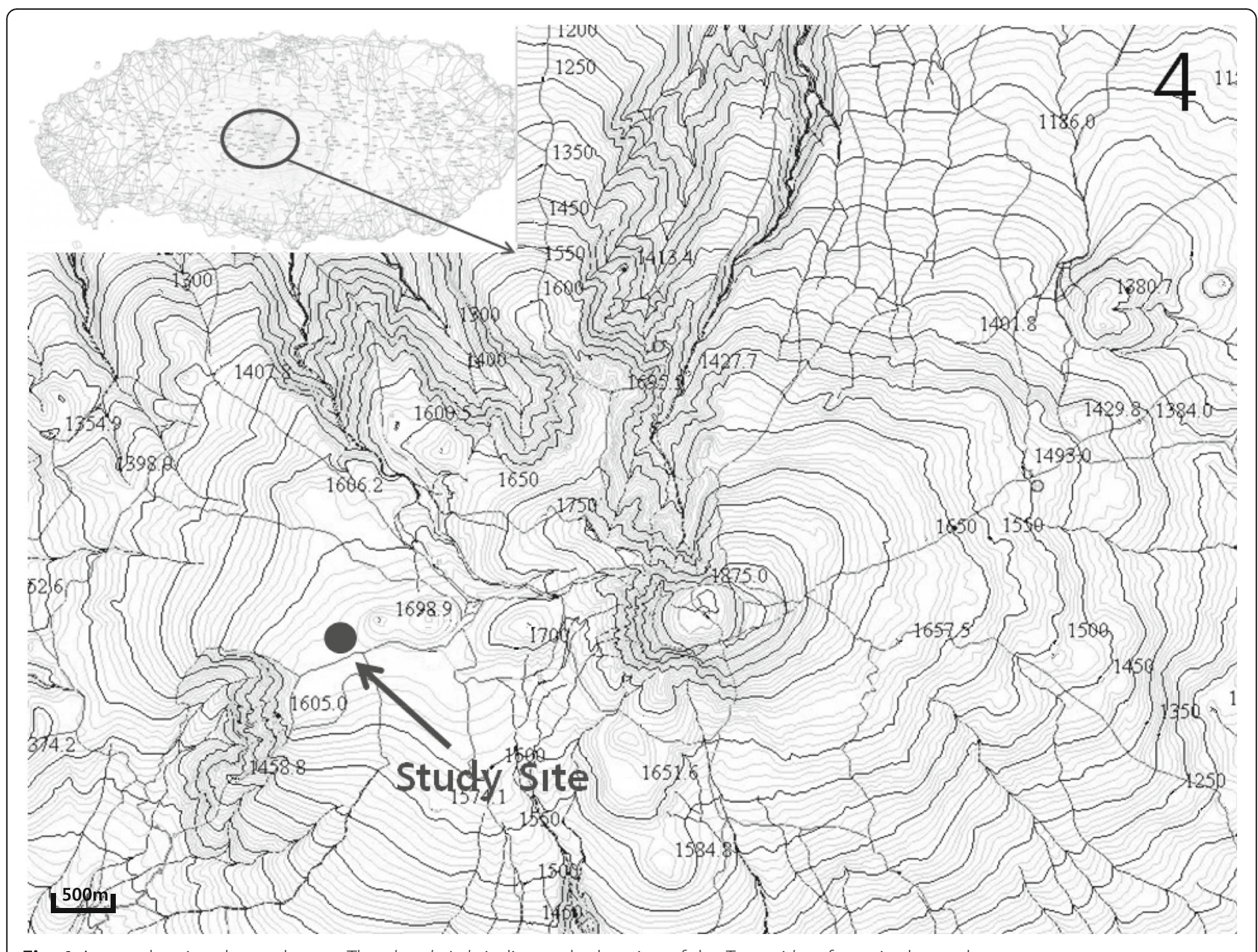

Fig. 1 A map showing the study area. The closed circle indicates the location of the T. cuspidata forest in the study area

\section{Litter production}

Five litter traps, sized $0.5 \times 0.5 \mathrm{~m}$, were installed in permanent quadrate in February 2012 to quantify the amount of organic carbon accumulates on forest floor. The litter was collected and separated into leaves, wood, reproductive organs, and others each season which were measured after being dehydrated at $65{ }^{\circ} \mathrm{C}$ in the dryer

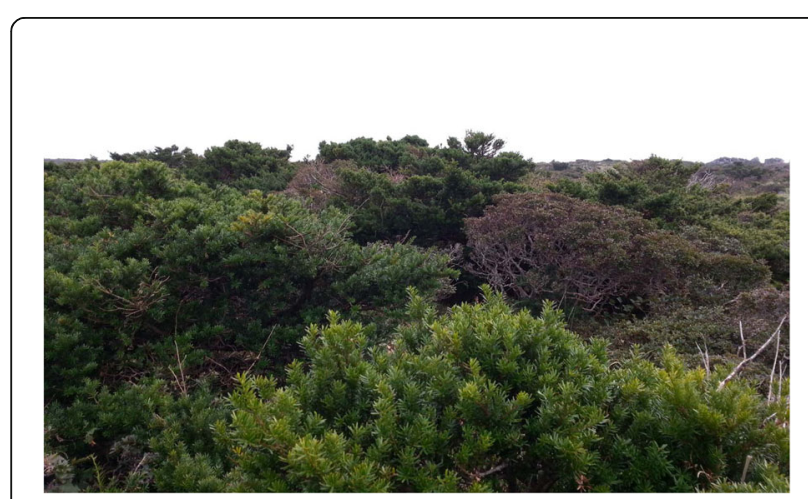

Fig. 2 View of the study site for more than $48 \mathrm{~h}$. The litter production per unit area were then calculated based on the dry mass of the collected litter each year.

\section{Forest floor litter}

Four smaller quadrate, sized $25 \times 25 \mathrm{~cm}$, were installed additionally outside the permanent quadrate in

Table 1 Allometric equations for each biomass component against the diameter at the breast height and tree height in different tree sizes

\begin{tabular}{llll}
\hline Species & D range & Allometry & Ref. \\
\hline T. cuspidata & Ws & 0.0361 (D2H) 0.9184 & Yasuhiro 2006 \\
& Wb & $0.0155(\mathrm{D} 2 \mathrm{H}) 0.8979$ & \\
$\begin{array}{l}\text { Rhododendron } \\
\text { schlippenbachii }\end{array}$ & W & 0.0471 (D) 2.8498 & Lee et al. 2004 \\
$\begin{array}{l}\text { Berberis amurensis } \\
\text { var. quelpaertensis }\end{array}$ & Ws & $0.667 \log (\mathrm{D} 2 \mathrm{H})-0.419$ & Kwak et al. 2004 \\
& Wb & $0.553 \log (\mathrm{D} 2004$ 2H)- & \\
& & 0.6419 &
\end{tabular}

$D$ diameter at the breast height, $W i$ (dry weight of each part), $H$ stem height, $s$ stem, $s b$ stem bark, $b$ branch 
study site to measure forest floor litter in each season without interference of existing quadrate. The litter was distinguished into $\mathrm{L}$ (litter) layer and $\mathrm{F}$ (fermentation) layer depending on the degree of decomposition. It was collected separately and measured after being dehydrated at $65{ }^{\circ} \mathrm{C}$ in the dryer for more than $48 \mathrm{~h}$ in the laboratory. This figure was used to calculate the amount of forest floor litter per unit area (ha).

\section{Amount of organic carbon}

The amount of organic carbon of plant biomass, litter production, and forest floor litter was estimated to be $45 \%$ of the dry mass (Houghton et al. 1983).

However, it was not possible to collect soil up to $30 \mathrm{~cm}$ in depth, which is general practice, as the layer of soil in the study site was extremely shallow. For this reason, the average soil depth $(30 \mathrm{~cm})$ of the study site was calculated and soil was collected accordingly to estimate the amount of organic carbon in soil. The soil collection was performed in the area close to quadrate that has similar soil properties to the study site because the region had permanent quadrate installed and study had to be conducted without any disturbance.

Soil was collected in intervals of $10 \mathrm{~cm}$ up to $30 \mathrm{~cm}$ in depth at three different spots. They were then sealed in envelops and taken to the laboratory. Five grams of air-dried soil was weighed after being dehydrated at $105{ }^{\circ} \mathrm{C}$ in the dryer for more than $48 \mathrm{~h}$. Then, it was baked in the electric furnace for about $4 \mathrm{~h}$ in order to calculate the amount of organic carbon by subtracting ash content from dry weight. The value obtained from subtraction was divided by 1.724 to convert it to organic carbon content (Black 1965).

Soil was collected at $10 \mathrm{~cm}$ intervals by using a cylinder soil sampler (diameter $=5 \mathrm{~cm}$, length $=5.1 \mathrm{~cm}$ ) to measure the bulk density of soil which was sealed and taken to the laboratory. The collected soil was dehydrated at $105{ }^{\circ} \mathrm{C}$ in the dryer until it reached constant weight and the value was divided by the volume to calculate bulk density. The gravel content was measured by filtering gravels from the collected soil using $2 \mathrm{~mm}$ net and they were weighed to calculate the ratio of gravel weight to the total weight.

The amount of accumulated organic carbon in soil per unit area was calculated from the values obtained above. The equation of Wang et al. (2002) was used considering the ratio of gravel between T. cuspidata forest and $J$. chinensis var. sargentii forest.

$\mathrm{SOC}\left(\mathrm{kg} / \mathrm{m}^{2}\right)=$ Bulk density $\left(\mathrm{ton} / \mathrm{m}^{3}\right) \times$ Organic carbon content $(\mathrm{g} / \mathrm{kg}) \times$ Soil depth $(\mathrm{m}) \times(1-$ Gravel ratio $)$

\section{Soil temperature and soil respiration}

Soil temperature was automatically monitored hourly over the study period by placing T\&D Thermo Recorder (TR-71) on top layer of soil $(5 \mathrm{~cm})$. Amount of $\mathrm{CO}_{2}$ released into the atmosphere from soil respiration was measured by using most widely used closed chamber method with a portable infrared gas analyzer (IRGA; EGM-4 PP system, UK). Cylinder chamber (diameter $100 \mathrm{~mm}$, height $=150 \mathrm{~mm}$ ) attached to the equipment was installed in the soil after removing the litter on forest floor. Soil respiration was measured three times at five different spots in the area where crowns overlap and root respiration was calculated by $46 \%$ of the total soil respiration.

\section{Results and discussion}

Distribution of plant organic carbon

Organic carbon distribution was 13.60 ton $\mathrm{C} \mathrm{ha} \mathrm{ha}^{-1}$ and 14.29 ton $\mathrm{C} \mathrm{ha}^{-1}$, respectively, in 2012 and 2013 with the average of 13.94 ton $\mathrm{C} \mathrm{ha}^{-1}$. And it increased by 0.69 ton $\mathrm{C} \mathrm{ha}^{-1}$ from 2012 to 2013 . Organic carbon distribution per organ was in descending order of stem, root and branch, then leaf. Average organic carbon distribution were as follows: stem of tree layer, 8.05 ton $\mathrm{C} \mathrm{ha}{ }^{-1}$ (57.73\%); branch of tree layer 2.55 ton $\mathrm{C} \mathrm{ha}^{-1}(18.29 \%)$; root, 2.65 ton $C$ ha $^{-1}$ (19.00\%); leaf and reproductive organs, 0.63 ton $\mathrm{C} \mathrm{ha}^{-1}$ (4.48\%); and herb layer, 0.07 ton $\mathrm{C}$ $\mathrm{ha}^{-1}(0.50 \%)$ (Fig. 3).

Organic carbon distribution of Pinus densiflora forest in subalpine zone of Kevo was 17.39 ton $\mathrm{C}$ ha- 1 and birch trees of Hardangervidda plateau in Norway was 15.81 ton $\mathrm{C}$ ha ${ }^{-1}$ (Kjelvik and Karenalmpi 1975). Moreover, organic carbon distribution of Abies koreana forest in Mt. Halla was 48.74 ton $\mathrm{C} \mathrm{ha}^{-1}$ and it was 41.17 ton $\mathrm{C} \mathrm{ha}^{-1}$ in 2013 which was higher than T. cuspidata forest (Jang et al. 2014). Low height is one of the characteristics of $T$. cuspidata forest in subalpine zone of Mt. Halla. Thus, it seems that organic carbon distribution is relatively low compared to other tall trees because organic carbon of woody plants are mostly stored in the stem. Organic carbon distribution of trees vary between species but it seems that tree height also is a factor.

\section{Amount of organic carbon accumulated on forest floor through litter production}

The amount of organic carbon introduced to forest floor from litter production was 0.67 ton $\mathrm{C} \mathrm{ha}{ }^{-1}$ year $^{-1}$ in 2012 and 0.74 ton $C$ ha $^{-1}$ year $^{-1}$ in 2013 with average of 0.71 ton $\mathrm{C} \mathrm{ha}^{-1}$ year $^{-1}$ (Fig. 4). The litter consisted of leaves (79.1\%), wood (10.0\%), reproductive organs $(5.2 \%)$, and others $(5.7 \%)$. In this study, most litter production occurred in fall. 


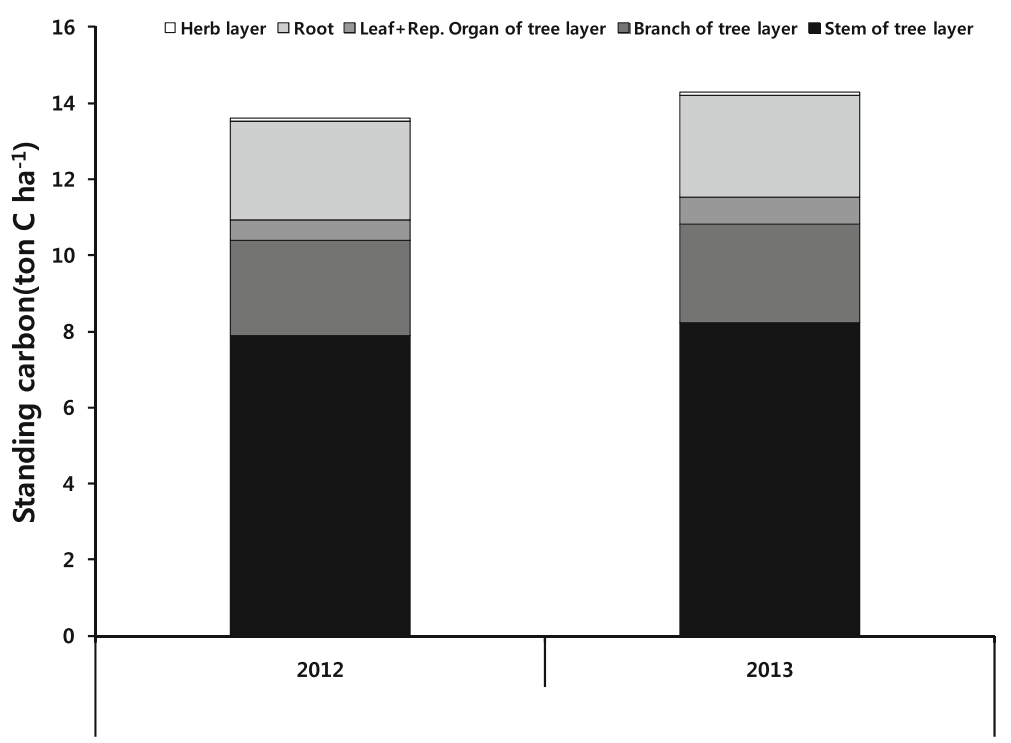

Fig. 3 Amount of annual organic carbon (ton $\mathrm{Cha}^{-1}$ ) of T. cuspidata forest in the study area

Similar result was observed from studies on Abies koreana and Pinus densiflora which are also coniferous trees. The composition varied for each plant community but leaves always had the highest ratio (Jang et al. 2014; Lee et al. 2013; Jeong et al. 2013). As result, we could see that deciduous trees litter and produce most litter in fall just like coniferous trees.

\section{Amount of organic carbon of forest floor litter}

The average amount of organic carbon distribution in forest floor litter was 0.76 ton $\mathrm{C} \mathrm{ha}^{-1}$ in $2012,0.70$ ton $\mathrm{C}$ ha
${ }^{-1}$ in 2013 , and the average was 0.73 ton $\mathrm{C} \mathrm{ha}^{-1}$. Average amount of organic carbon in L layer was 0.47 ton $\mathrm{C} \mathrm{ha}{ }^{-1}$, 0.21 ton $\mathrm{C} \mathrm{ha}^{-1}$ greater than $\mathrm{F}$ layer which was only 0.26 ton $\mathrm{C} \mathrm{ha}^{-1}$ (Fig. 5). Overall amount of organic carbon of forest floor litter in 2013 decreased from 2012. Abies koreana forest, distributed in subalpine zone of Mt. Halla, also showed similar pattern even though its L layer seem to have a lot of forest floor litter (Jang et al. 2014). However, L layer was lower than F layer of Pinus densiflora forest in Mt. Worak even though it was the same coniferous tree. Such phenomenon could be observed not only from

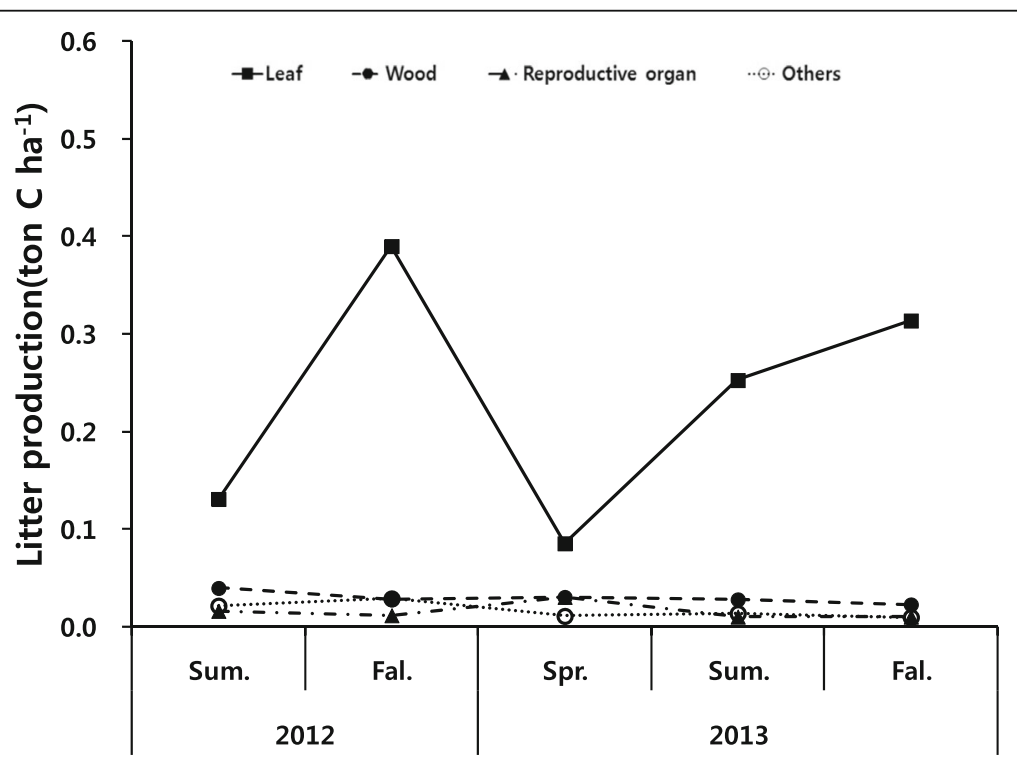

Fig. 4 Seasonal changes of organic carbon of litter production (ton C ha ${ }^{-1}$ ) of the T. cuspidata forest from 2012 to 2013 in the study area 


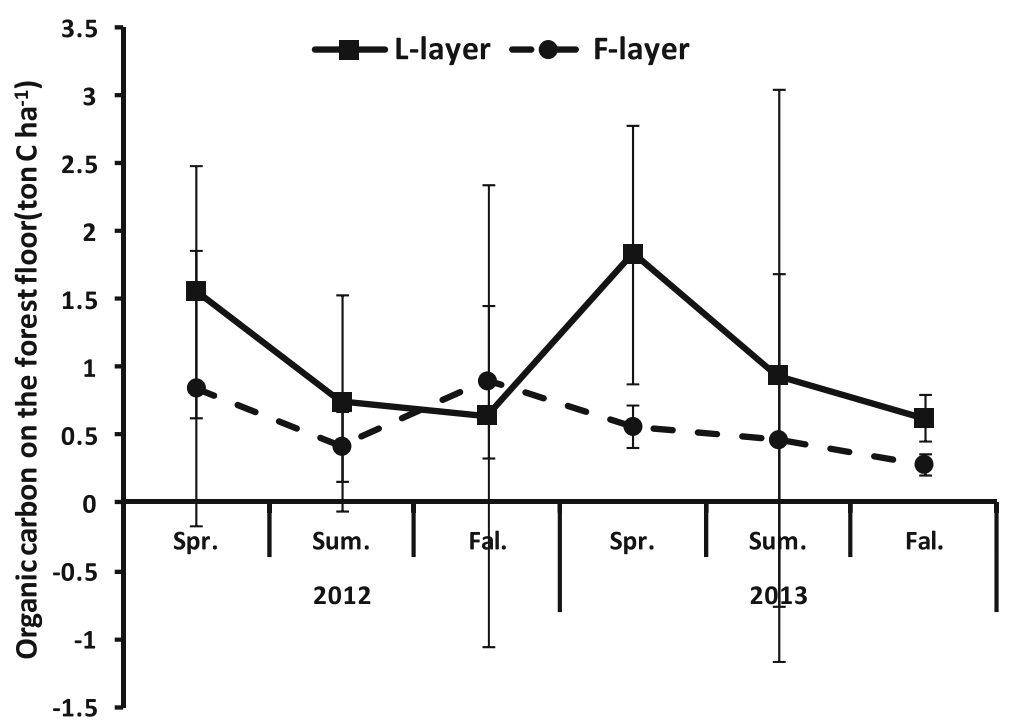

Fig. 5 Organic carbon (ton $\mathrm{C}$ ha ${ }^{-1}$ ) on the forest floor of $T$. cuspidata forest in the study area

evergreen coniferous trees but also from deciduous broadleaved trees. Family Fagaceae, Q. mongolica, and Q. variabilis Blume, which are deciduous broad-leaved trees showed higher value in F layer than L layer but Q. serrata showed higher value in L layer (Lee 2014). Forest floor litter of Pinus densiflora was greater in L layer than F layer in the study of Lee et al. (2013). Therefore, the amount of organic carbon in each layer of forest floor litter is more affected by geographical characteristics, such as temperature, rainfall, and soil property, than characteristics of species.
Bulk density and accumulated organic carbon in soil

Bulk density of soil was on average $5.57 \mathrm{~g} / \mathrm{cm}^{3}$ at $10 \mathrm{~cm}$ underground, $5.23 \mathrm{~g} / \mathrm{cm}^{3}$ at $20 \mathrm{~cm}$, and $4.54 \mathrm{~g} / \mathrm{cm}^{3}$ at $30 \mathrm{~cm}$. Organic carbon at $30 \mathrm{~cm}$ soil depth was 55.30 ton $\mathrm{C} \mathrm{ha} \mathrm{ha}^{-1} 30 \mathrm{~cm}^{-1}$ depth $^{-1}$ in 2012, 46.96 ton $\mathrm{C} \mathrm{ha}^{-1} 30 \mathrm{~cm}^{-1} \mathrm{depth}^{-1}$ in 2013, and the average over the study period was 51.13 ton $\mathrm{C} \mathrm{ha}^{-1} 30 \mathrm{~cm}$ ${ }^{-1}$ depth $^{-1}$ (Fig. 6). Accumulated organic carbon of soil decreased with depth.

Accumulated organic carbon in soil of Abies koreana forest located in Yeongsiloreum region of Mt.

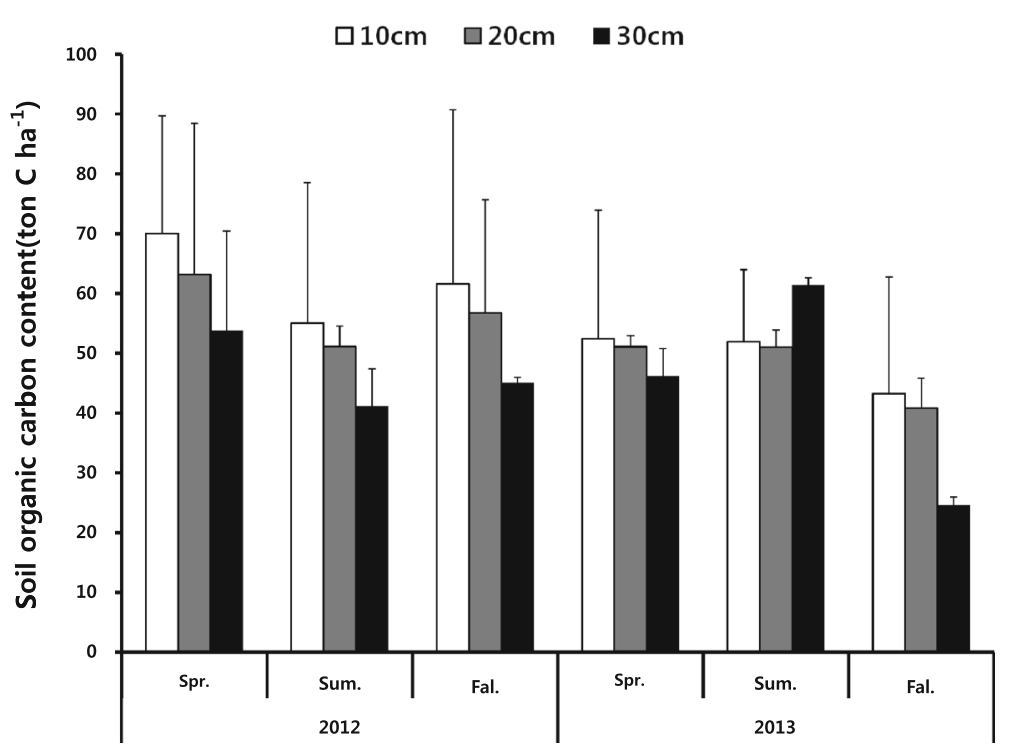

Fig. 6 Soil organic carbon (ton $\mathrm{Cha}^{-1}$ ) along the soil depth at the T. cuspidata forest in the study area 
Halla was 49.53 ton $\mathrm{C} \mathrm{ha}{ }^{-1} 20 \mathrm{~cm}^{-1}$ depth $^{-1}$ which decreased with depth (Jang et al. 2014). Generally, organic carbon of soil decreases with depth (Eswaran et al. 1995). Pinus densiflora forest in Namsan was 60.70 ton $\mathrm{C} \mathrm{ha}$ and 60.70 ton $\mathrm{C}$ ha ${ }^{-1}$ (Jeong et al. 2013) in Mt. Worak was 189.439 ton $\mathrm{C} \mathrm{ha}^{-1}$ which were both greater than the result obtained from this study (Lee 2014). The reason for such result can be attributed to the shallow depth of soil in Mt. Halla that contains low level of organic carbon.

\section{Amount of soil respiration}

Soil respiration is the process of $\mathrm{CO}_{2}$ being released into the atmosphere from soil within the greater context of carbon cycle in forest ecosystem. Soil respiration is caused by respiration of microorganisms and plant roots in soil. The study site released about 10.93 ton $\mathrm{CO}_{2} \mathrm{ha}^{-1}$ year $^{-1}$ of carbon through soil respiration in 2012. It was highest with 2.42 ton $\mathrm{CO}_{2}$ ha ${ }^{-1}$ month $^{-1}$ in July and lowest with 0.23 ton $\mathrm{CO}_{2}$ ha ${ }^{-1}$ month $^{-1}$ in December (Fig. 7). Summer always had the highest soil respiration. It is widely known that soil temperature, moisture, and organic matter content are the main factors that affect soil respiration (Lloyd and Taylor 1994; Raich and Potter 1995). Furthermore, it was revealed that, among those factors, soil respiration is mainly led by soil temperature which has high correlations (Liu et al. 2002). This is probably because the increase in soil temperature accelerates growth of plants and activities of microorganisms that leads to more $\mathrm{CO}_{2}$ efflux.

\section{Organic carbon budget and distribution of $T$. cuspidata forest}

Figure 8 shows the budget and distribution of organic carbon for each carbon storage in T. cuspidata forest. In 2012, total of 1.16 ton $\mathrm{C} \mathrm{ha}^{-1}$ carbon from the atmosphere was stored in the entire plant: 0.55 ton $\mathrm{C} \mathrm{ha}^{-1} \mathrm{year}^{-1}$ in leaf and reproductive organ, 0.34 ton $\mathrm{C} \mathrm{ha}^{-1} \mathrm{yr}^{-1}$ in stems, 0.10 ton $\mathrm{C}$ ha ${ }^{-1}$ year $^{-1}$ in branches, 0.10 ton $\mathrm{C} \mathrm{ha}{ }^{-1}$ year $^{-1}$ in roots, and 0.07 ton $\mathrm{C} \mathrm{ha}^{-1} \mathrm{year}^{-1}$ in herb layer. In addition, the total organic carbon in the litter was 0.67 ton $\mathrm{C}$ ha $^{-1}$ year $^{-1}$ which consisted of the following: 0.52 ton $\mathrm{C}$ ha $^{-1}$ year $^{-1}$ in leaves (77.61\%), 7.88 ton $\mathrm{C} \mathrm{ha}^{-1}$ year $^{-1}$ in wood (10.45\%), 0.03 ton $\mathrm{C} \mathrm{ha}{ }^{-1}$ year $^{-1}$ in reproductive organ (4.48\%), and 0.05 ton $\mathrm{C} \mathrm{ha}{ }^{-1}$ year $^{-1}$ in others (7.46\%). The average organic carbon in forest floor litter was 0.76 ton $\mathrm{C} \mathrm{ha}^{-1}$ in total which comprised of 0.44 ton $\mathrm{C} \mathrm{ha}{ }^{-1}$ in $\mathrm{L}$ layer and 0.32 ton $\mathrm{C} \mathrm{ha}{ }^{-1}$ in $\mathrm{F}$ layer. $\mathrm{L}$ layer was 0.12 ton $\mathrm{C}$ ha $^{-1}$ greater than $\mathrm{F}$ layer. 2.90 ton $\mathrm{C} \mathrm{ha} \mathrm{hear}^{-1}$ of organic carbon was released into the atmosphere through soil respiration (Fig. 8). Net ecosystem production (NEP) of the $T$. cuspidata forest was -1.74 ton $\mathrm{C} \mathrm{ha}^{-1} \mathrm{year}^{-1}$ based on the difference between Net primary production (NPP) and soil respiration. Hence, T. cuspidata forest in this study released more $\mathrm{CO}_{2}$ into atmosphere than it absorbed in 2012 and it acted as a negative (-) factor in the atmospheric environment.

The amount of $\mathrm{CO}_{2}$ released from T. cuspidata forest in this study site was estimated to be about $-36,714$ $\mathrm{KRW} /$ ha based on the value of carbon per ton suggested by Douglas et al. (2001).

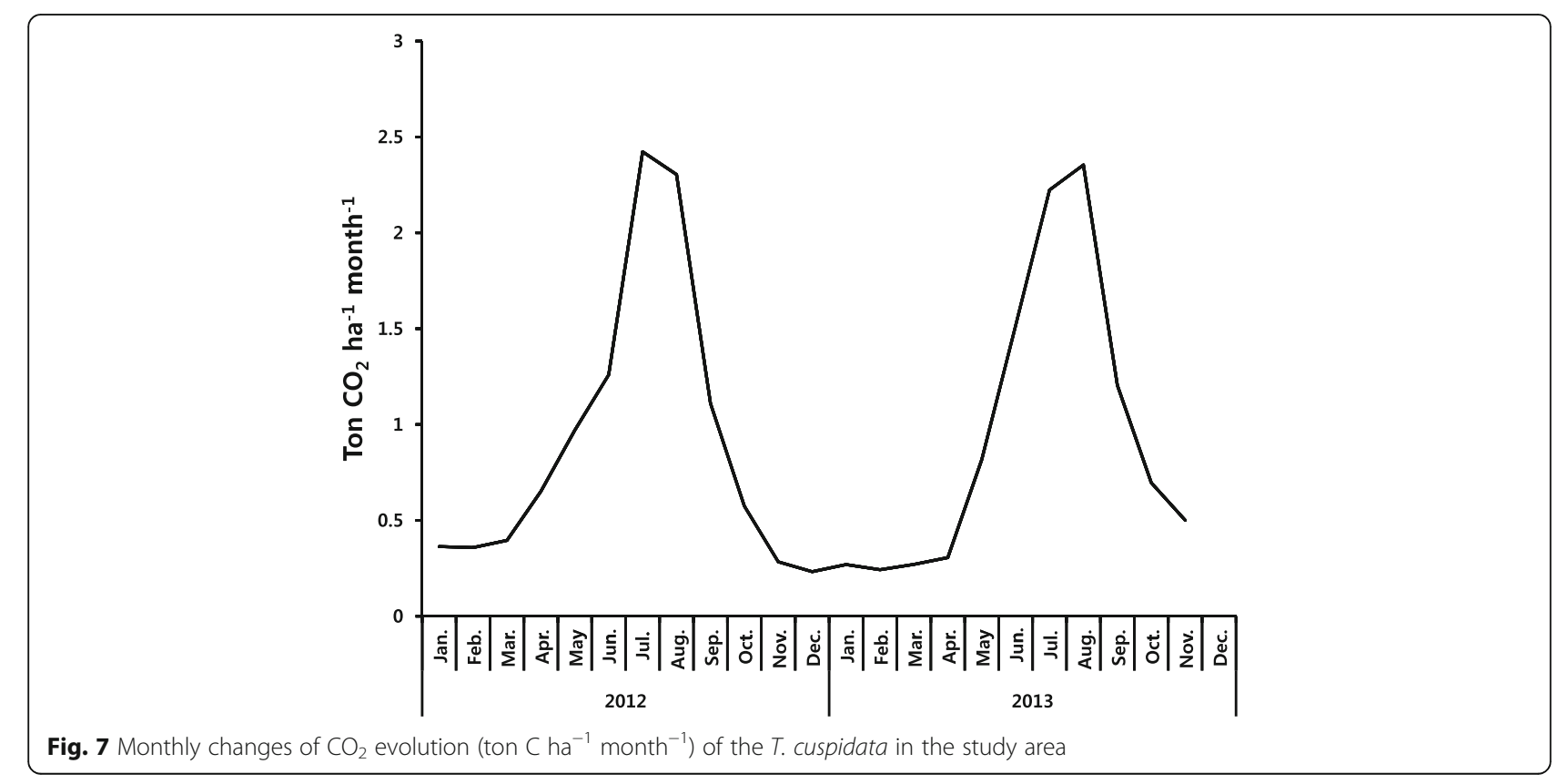




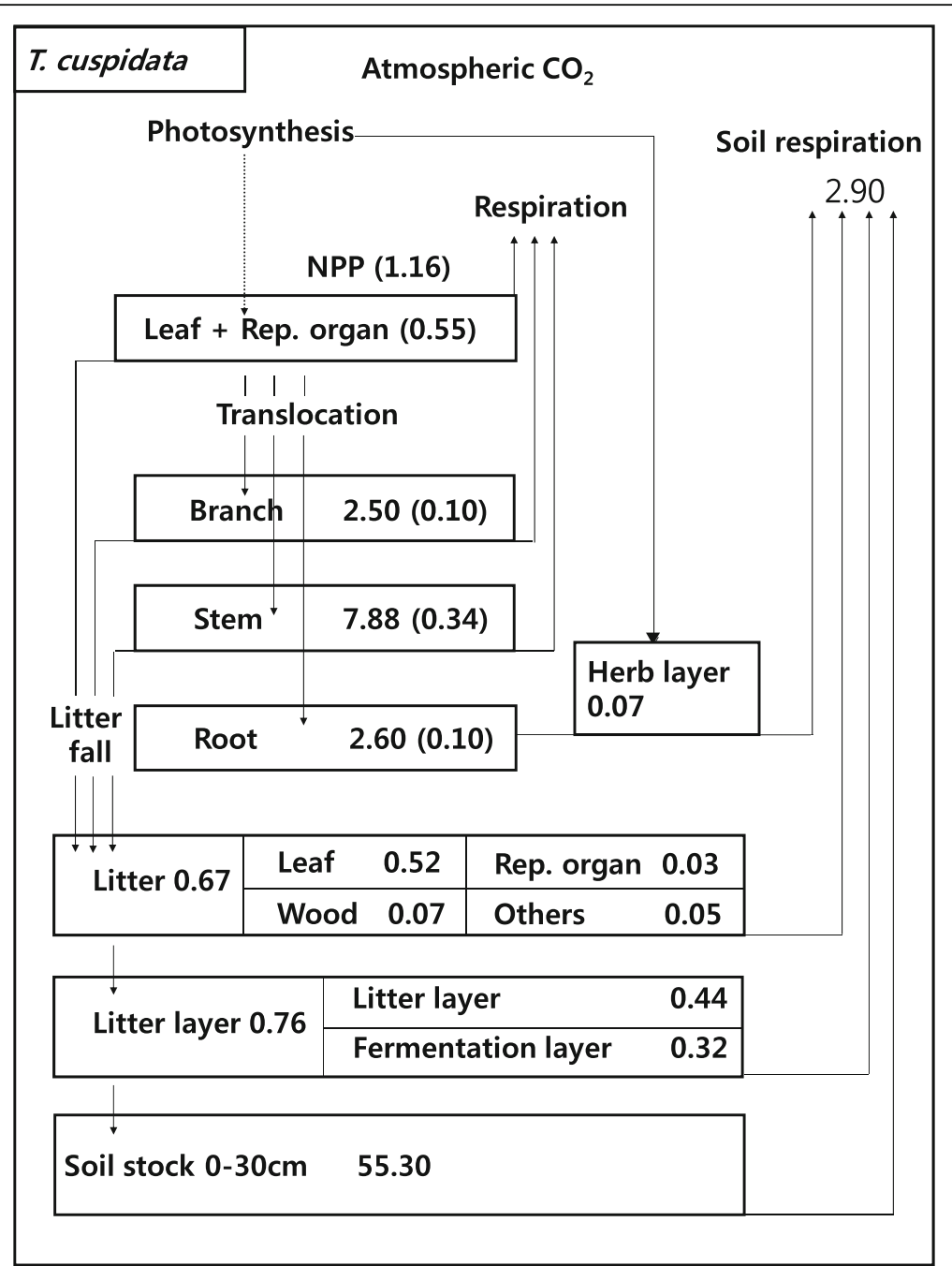

Fig. 8 Compartment model showing the distribution and flow organic carbon in the T. cuspidata forest in 2012. Boxes: standing carbon (ton/ha). Arrows: flux (ton C ha ${ }^{-1} \mathrm{year}^{-1}$ ). Numerals in parenthesis indicate NPP (ton C ha ${ }^{-1} \mathrm{year}^{-1}$ )

NPP continually decreased over the last 5 years even in Abies koreana community in subalpine zone of the same region due to climate change (Jeong 2015). Climate change affects NEP in various ways. The increase in temperature leads to decrease in soil moisture and increase in plant respiration that causes reduction in NEP (Melillo et al. 1993). Witsaeoreum observatory, in proximity to this study site, recorded average temperature of $5.4{ }^{\circ} \mathrm{C}$ in 2012 and $6.5{ }^{\circ} \mathrm{C}$ in 2013 with the difference of $1.1{ }^{\circ} \mathrm{C}$. The maximum average temperature was $16{ }^{\circ} \mathrm{C}$ and minimum average temperature was $5{ }^{\circ} \mathrm{C}$ with increase (Korea Meteorological 2013; 2014. Thus, more carbon is expected to be released in 2013 .

\section{Conclusions}

In the subalpine zone at Mt. Halla, the amount of plant's organic carbon of T. cuspidata forest had lower than other region that was similar altitude. However, the amount of organic carbon in the soil of forest was higher than other region. The net ecosystem production based on the difference between net primary production of organic carbon and soil respiration was -1.74 ton $\mathrm{C} \mathrm{ha}{ }^{-1} \mathrm{yr}^{-1}$ releasing more carbon than it absorbed. As a result, T. cuspidata forest in subalpine zone at Mt. Halla was high function as a carbon pool.

\section{Abbreviations}

NEP: Net ecosystem production; NPP: Net primary production

\section{Acknowledgements}

This study is funded by the National Research Foundation of Korea. The foundation is not involved in any way in the preparation of this manuscript or the decision to submit it.

\section{Funding}

This study was partially supported by Mid-career Researcher Program (NRF-2016R1A2B1010709) through NRF grant funded by the MEST. 


\section{Availability of data and materials}

Not applicable.

\section{Authors' contributions}

All authors conducted a survey together during the study period. JRH wrote the manuscript. YYH participated in the design of the study and examined the manuscript. All authors read and approved the final manuscript.

\section{Competing interests}

The authors declare that they have no competing interests.

\section{Consent for publication}

Not applicable.

\section{Ethics approval}

Not applicable.

\section{Author details}

'Department of Biology, Kongju National University, Gongju, South Korea. ${ }^{2}$ Division of Basic Research, National Institute of Ecology, Seocheon-gun, South Korea. ${ }^{3}$ Division of Ecological Conservation, National Institute of Ecology, Seocheon-gun, South Korea.

\section{Received: 7 October 2016 Accepted: 6 January 2017}

Published online: 28 January 2017

\section{References}

Barbour, M. G., Burk, J. H., \& Pitts, W. D. (1999). Terrestrial plant ecology (p. 634). Menlo Park: The Benjamin Cummings.

Black, C. A. (1965). Methods of soil analysis, part 2 (pp. 1562-1565). Madison: American Society of Agronomy, Inc.

Dixon, R. K., Brown, S., Houghton, R. A., Solomon, A. M., Trxler, M. C., \& Wisniewski, J. (1994). Carbon pools and flux of global forest ecosystems. Science, 263, 185-190.

Douglas, C. M., Elizabeth, I. D., \& David, A. E. (2001). Modelling the non-market environmental costs and benefits of biodiversity projects using contingent valuation data. Ecvironmental and Resource Economics, 18(4), 391-410.

Eswaran H, Ban den Berg E, Reich P, Kimble J (1995). Global soil carbon resources. In Soils and Global Change (Lal R Kimble JM, Levine E, Stewart BA, eds), (p. 27-44). Boca Raton: CRC-Press.

Houghton, R. A., Hobbie, J. E., Melillo, J. M., Moore, B., Shaver, G. R., \& Woodwell, G. M. (1983). Changes in the carbon content of terrstrial biotal biota and soils between 1860 and 1980: a net release of $\mathrm{CO}_{2}$ to the atmosphere. Ecological Monoger., 53, 235-262.

Hu, H., \& Wang, G. G. (2008). Changes in forest biomass carbon storage in the south Carolina piedmont between 1936 and 2005. Forest Ecology and Management, 255(5 6), 1400-1408.

IPCC. (2007). Climate change 2007: Impacts, adaptation and vulnerability. Food, fiber and forest products, in: Impacts, adaptation and vulnerability. Cambridge: Cambrige Univ. Press.

IPCC (2013). Climate Change 2013: The physical science basis. Contribution of working group I to the fifth assessment report of the intergovermmental panel on climate change. Cambridge: Cambridge Univ. Press.

Ito A., \& Oikawa T. (2004). Global mapping of terrestrial primary productivity and light-use efficiency with a process-based model. Global Environmental Change in the Ocean and on Land. P. 343-358.

Jang, S. K., Jung, H. S., \& Yun, H. I. (1998). Global warming and recent retreat of an ice cliff on King George island, South Shetland Islands, Wet Antarctica. Journal of the Korean Earth Science Society, 19(1), 101-106.

Jang, R. H., Cho, K. T., \& You, Y. H. (2014). Annual biomass production and amount of organic carbon in Abies koreana forest of subalpine zone at Mt. Halla. Korean Journal of Environment and Ecology, 28(6), 627-633.

Jeong, H. M. (2015). Carbon distribution and budget of Quercus glauca community in warm-temperate forest and Abies korean a community in sub-alpine forest in Jeju island. Doctor's Thesis. Kongju: University of Kongju.

Jeong, H. M., Kim, H. R., Shin, D. H., Lee, K. M., Lee, S. H., Han, Y. S., Jang, R. H., Lee, S. K., Kim, T. K., \& You, Y. H. (2013). Litter production and soil organic carbon dynamincs of Pinus densiflora, Quercus mongolica and Robinia pseudo-acacia forests in Mt Nam. Korea Journal of Environmental Biology., 31(2), 87-95.
Johnson, F. L., \& Risser, P. G. (1974). Biomass annual net primary production and dynamics of six mineral elements in a post oak*blackjack oak forest. Ecology, $55,1246-1258$

Kim, J. M. (1976). Ecology of Korean plants, A modern science book 15. South Korea: Junpa Science Publisher.

Kjelvik, S., \& Karenalmpi, L. (1975). Plant biomass and primary production of Fennoscandian subarctic and subalpine forests and of alpine willow and heath ecosystems. Fennoscandian Tundra Ecosystems., 16, 111-120.

Kong, W. S. (2002). Species composition and distribution of Korean alpine plants. Journal of Korean Geographical Society, 37(4), 357-370.

Korea Meteorological Administration. (2009). Whitepaper of environment. Seoul: Korea Meteorological Administration; P. 65.

Korea Meteorological Administration. (2013). Annual report of automatic weather station data. Seoul: Korea meteorological administration; P. 834.

Korea meteorological Administration. (2014). Annual report of automatic weather station data (p. 836). Seoul: Korea meteorological administration.

Korea Meteorological administration. (2016). Eaeth atmospheric monitoring report in 2015 year (p. 226). Seoul: Korea Meteorological administration.

Kwak, Y. S. Hur, Y. K. Song, J. H. \& Hwangbo, J. K. (2004). Quantification of atmospheric purification capacity by afforestation impact assessment of Kwangyang steel works. RIST Research paper, 18(4), 334-340.

LaMarche, V. C., Graybill, D. A., Fritts, H. C., \& Rose, M. R. (1984). Increasing atmospheric carbon dioxide: tree ring evidence for growth enhancement in natural vegetation. Science, 225, 1019-1021

Law, B. E., Thornton, P. E., Irvine, J., Anthorni, P. M., \& Vantuyl, S. (2001). Carbon storage and fluxes in ponderosa pine forests at different developmental stages. Global Change Biology, 7, 755-777.

Lee, K. S., Choung, Y. S., Kim, S. C., Shin, S. S., Ro, C. H. \& Park, S. D. (2004). Development of vegetation structure after forest fire in the Eas coastal region, Korea. Journal of Ecology and Environment, 27(2), 99-106.

Lee, S. H. (2014). Carbon distribution and budget of the dominant deciduous plant communities in Worak national park. Master's Thesis. Kongju: University of Kongju.

Lee, Y. Y., \& Mun, H. T. (2001). A study of the soil respiration in a Quercus acutissima forest. Journal of Ecology and Environment, 24(3), 141-147.

Lee, J. Y., Kim, D. K., Won, H. Y., \& Mun, H. T. (2013). Organic carbon distribution and budget in the Pinus densiflora at Mt. Worak national park. Korean Society of Environment \& Ecology, 27(5), 561-570.

Lee, K. S., Kim SC, Jeong YI, Kim JS, Oh SH, Choi SH, Kang HG (2013). Vegetation structure and dynamics: the first 10 years of KNLTER (2004-2013) final report. National Institute of Environmental Research Report; p. 47-86.

Liu, X., Wan, B., Hui, D., \& Luo, Y. (2002). Response of soil $\mathrm{CO}_{2}$ efflux to water manipulation in a tallgrass prairie ecosystem. Plant and Soil, 240, 213-223.

Lloyd, J., \& Taylor, J. A. (1994). On the temperature dependence of soil respiration. Functional Ecology, 8, 315-323.

McKenny, G. (2004). W., D. Yemshanov, G. Fox and E. Ramlal. Cost estimate for carbon sequestration from fast growing popular plantation in Canada. Forest Policy and Economics, 6, 345-358.

Melillo, J. M., McGuire, A. D., Kicklighter, D. W., Moore, B., Vorosmarty, C. J. \& Schloss, A. L. (1993). Global climate change and terrestrial net primary production. Nature, 363, 234-363.

Ovington, J. D., \& Heitkamp, D. (1960). The accumulation of energy in forest plantation in Berlin. Ecology, 48, 639-646.

Park, I. H., Kim, D. Y., Son, Y. H., Yi, M. J., Jin, H. O., \& Choi, Y. H. (2005). Biomass and net production of a natural Quercus mongolica fores in Namsan, Seoul. Korean Society of Environment \& Ecology, 19(3), 299-304.

Raich, J. W. \& Potter, C. S. (1995). Global patterns of carbon dioxide emission from soil. Global biochemical Cycle., 9, 23-36.

Richards, K. R., \& Stokers, C. (2004). A review of forest carbon sequestration cost studies: a dozen years of research. Climate Change, 63, 1-48.

Sohngen, B., \& Mendelsohn, R. (2003). An optimal control model of forest carbon sequestration. American Journal of Agricultural Economics, $85,448-457$.

Song, K. M. (2011). Vegetation structure and dynamics of Abies koreana forests on Mt. Halla. Docter's Thesis. Jeju: University of Jeju.

Wang, G., Qian, J., Cheng, G., \& Lai, Y. (2002). Soil organic carbon pool of grassland on the Qunghai-Tibetan plateau and its global implication Sci. Total Environment., 29, 207-217.

WMO. (2016). WOM Greenhouse gas bulletin: The state of greenhouse gases in the atmosphere based on global observations through 2015. Weather Climate Water, 12, 1-8. 
Yasuhiro, K. (2006). Spatial pattern and regeneration dynamics in a temperate Abies-Tsuga forest in southwestern Japan. Journal of Forest Research, 11, 191-201.

Yeocheon Ecological Reserch Society. (2005). Modern ecology experiment. Seoul: Gyomoon Publisher; 370p.

Yim, Y. J. (1977). Distribution of forest vegetation and climate in the Korean peninsula. IV. Zonal distribution of forest vegetation in relation to thermal climate. Japanese Journal of Ecology, 27, 169-278.

You, Y. H., Mun, H. T., Cho, S. R., Cho, K. T. (2015). Field biology and ecology experiment book. Incheon: Jinyoung Publisher; 358p.

Submit your next manuscript to BioMed Central and we will help you at every step:

- We accept pre-submission inquiries

- Our selector tool helps you to find the most relevant journal

- We provide round the clock customer support

- Convenient online submission

- Thorough peer review

- Inclusion in PubMed and all major indexing services

- Maximum visibility for your research

Submit your manuscript at www.biomedcentral.com/submit
Biomed Central 